\title{
EXAMINING THE EVOLUTION OF WAQF REGULATIONS IN SELANGOR: AN ANALYSIS OF THE GOVERNANCE FRAMEWORK AND TRANSFORMATIVE APPROACH
}

\author{
Zati Ilham Abdul Manaf* \\ Sharifah Zubaidah Syed Abdul Kader** \\ Nor Asiah Mohamad ${ }^{* * *}$
}

\begin{abstract}
The inadequacy of comprehensive laws for Waqf administration is one of the main issues that has limited the development of Waqf in Malaysia. Whilst most states in Malaysia rely on their Administration of Islamic Law enactments, in 1999 Selangor pioneered a Waqf enactment which specifically oversees Waqf administration and management. With the promulgation of the Selangor Waqf Enactment 1999, the administration of Waqf in Selangor became more regulated and structured. However, as matters pertaining to Waqf practices became more complex, Selangor repealed its 1999 Waqf Enactment and replaced it with the 2015 Waqf Enactment. This research therefore analyses the evolution of Waqf in Selangor through the two respective enactments, by identifying the changes in practices and scrutinising the rationales for the development of the laws. It also analyses how the laws have impacted the Waqf governance framework in the state. By assessing the position of the 2015 Waqf Enactment, it determines whether the current legislative demand posed by Waqf development in the state is met and whether the change in approach should be followed by other states in Malaysia. Doctrinal legal research is utilised to examine the two enactments respectively. Legislative Assembly Proceedings related to the promulgation of the respective enactments were also examined to further understand the reasoning behind the repeal and the introduction of certain provisions. It is found that although the 2015 Waqf Enactment is more comprehensive
\end{abstract}

\footnotetext{
* Ph.D Student at the Ahmad Ibrahim Kulliyyah of Laws, International Islamic University of Malaysia. Email: ilham.manaf@gmail.com.

** Associate Professor at the Department of Civil Law, Ahmad Ibrahim Kulliyyah of Laws, International Islamic University of Malaysia. Email: sharifahz@iium.edu.my.

*** Associate Professor at the Department of Civil Law, Ahmad Ibrahim Kulliyyah of Laws, International Islamic University of Malaysia. Email: norasiahm@iium.edu.my.
}

[Received: 22 May 2019, Accepted: 23 July 2019, Published: 30 December 2019] 
than the 1999 Waqf Enactment, further improvements can be made to better achieve transparency and accountability on the part of the Waqf administrators.

Keywords: Waqf, Selangor, legislation, evolution

\title{
MENELITI EVOLUSI UNDANG-UNDANG WAKAF DI SELANGOR: SUATU ANALISA KE ATAS KERANGKA PENTADBIRAN DAN PENGGUNAAN PENDEKATAN TRANSFORMASI
}

\begin{abstract}
ABSTRAK
Salah satu isu utama yang membataskan pembangunan Wakaf di Malaysia adalah kekurangan dari segi undang-undang yang komprehensif dalam mentadbir hal ehwal pengurusan Wakaf. Walaupun kebanyakan negeri-negeri di Malaysia bergantung kepada Enakmen Pentadbiran Agama Islam masing-masing bagi tujuan pentadbiran Wakaf, Selangor telah mengambil langkah awal dengan menggubal satu enakmen yang khusus untuk mentadbir dan mengurus Wakaf pada tahun 1999. Dengan adanya Enakmen Wakaf Selangor 1999 ini, pentadbiran Wakaf di Selangor telah menjadi lebih teratur dan berstruktur. Walau bagaimanapun, dengan peredaran masa, amalan Wakaf di Selangor telah menjadi lebih kompleks. Oleh itu, Selangor telah memutuskan untuk memansuhkan Enakmen Wakaf Selangor 1999 dan telah menggantikannya dengan Enakmen Wakaf Selangor 2015. Justeru, kajian ini dijalankan untuk menganalisa evolusi institusi Wakaf di Selangor khususnya dengan mengenal pasti perubahan dalam amalan dan meneliti rasional terhadap perubahan undang-undang wakaf di Selangor. Selain itu, kajian ini juga mengkaji kesannya terhadap kerangka tadbir urus wakaf di negeri itu. Kajian ini turut mengenal pasti kedudukan Enakmen Wakaf 2015 dan samaada ia dapat memenuhi keperluan pentadbiran wakaf di negeri itu. Untuk mengenalpasti perubahan yang telah diperkenalkan, Enakmen Wakaf 1999 dan Enakmen Wakaf 2015 telah dianalisa. Menggunakan pendekatan metod analisis data utama dan sekunder, Prosiding Dewan Undangan yang berkaitan dengan penggubalan Enakmen Wakaf 2015 juga telah dirujuk secara terperinci untuk memahami tujuan peruntukan tersebut diperkenalkan atau dimansuhkan. Dapatan kajian menunjukkan bahawa walaupun Enakmen Wakaf 2015 dilihat sebagai lebih komprehensif, namun penambahbaikan dalam aspek ketelusan dan akauntabiliti oleh
\end{abstract}


pentadbir wakaf boleh diperkenalkan untuk menjadikan enakmen wakaf ini lebih berkesan.

Kata Kunci: Wakaf, Selangor, perundangan, evolusi

\section{INTRODUCTION}

Waqf is a product of ijtihad ${ }^{1}$ during the time of the Prophet (SAW) as there is no direct provision on this perpetual charitable institution in the Quran. The practice of Waqf is based on the hadeeth, sunnah and practices of the sahabah (Prophet's companions). It has been recorded that in the early practices of Waqf, it was up to the waqif to set up administrative guidelines, criteria for beneficiaries and principles for revenue distribution. ${ }^{2}$ However, with the complexity of the present economy, it is no longer feasible for Waqf to be exclusively selfregulated. With the centralization of Waqf management, there is a demand for Waqf institutions to be regulated and monitored. ${ }^{3}$

The benevolent practice of Waqf was adopted in the states of Malaya with the introduction of Islam in the states since the 9th century AD. ${ }^{4}$ In Malaysia, the practice of Waqf has undergone several stages; pre-colonial period, colonization period and post-colonization. Evolving along societal practices, Waqf continued to develop further and therefore various phases in terms of its policies, practices and reception has been recorded. It is not the intention of this paper to delve into the history of Waqf in Malaysia, however a brief mention of the

${ }^{1}$ Decision made based solely on one's own judgment. See: Ahmed Akgunduz, Introduction to Islamic Law (Rotterdam: IUR Press, 2010).,116.

${ }^{2}$ Mohammad Abdullah, "A New Framework for Corporate Governance for Waqf: A Preliminary Proposal," Islam and Civilisational Renewal 6, no. 3 (2015): 356.

${ }^{3}$ Abdullah, 353.

${ }^{4}$ Although there are many theories on when Islam came to the Malay States, a recent research paper has concluded that it is in the 9th century in the state of Kedah. See: Salehuddin Md. Dahlan, Zulkifli Yunos, and Nor Asiah Mohamad, "The Earliest Waqfs in Malaysia," (paper presented at International Conference on History and Governance of Awqaf in South and Southeast Asia, 2018). 
historical events in Selangor is included to fully understand the reasoning behind the evolution of its Waqf legislations.

We perceive that discussions on the evolution of Waqf regulations is important as it affects the effectiveness of the governance of a Waqf administration. A good Waqf governance framework will improve the overall credibility of the Waqf administrators and enhance the confidence of the stakeholders. According to Mohammad Abdullah, this will bring greater accountability and transparency in the Waqf operations and will enhance the viability of Waqf in the state. ${ }^{5}$

The reason why the Waqf (State of Selangor) Enactment 2015 (2015 Waqf Enactment) was chosen as the subject of this study is due to the fact that Selangor is the only state in Malaysia which had repealed its previous Waqf law and had substituted it with a new Waqf Enactment which is deemed to be more comprehensive. With this, it is hoped that we can see the evolution of Waqf regulation which had taken place.

The first part of this paper will cover the legal history of Waqf in Selangor during both the pre- and post-independence era. This will include the applicable rules and practices as well as the appointed managers and administrators of Waqf in the state in those periods.

The second part of the paper will open with a cursory examination of the Waqf (State of Selangor) Enactment 1999 (1999 Waqf Enactment). This review will be followed by a comparative analysis between the 2015 Waqf Enactment and the 1999 Waqf Enactment to understand the changes introduced. The abovementioned analysis will cover various aspects including the scope and new powers introduced by the 2015 Enactment such as power to delegate its duties and the power to issue Waqf shares. An earlier analysis of the 2015 Waqf Enactment has been conducted by Siti Mashitoh whereby changes introduced by the enactment were analysed through the Shariah perspective. ${ }^{6}$ This article aims to provide further analysis from the legal viewpoint and to deduce the reasoning behind the introduction of the new provisions and the problems it aims to tackle. Legislative

${ }^{5}$ Mohammad Abdullah, "A New Framework for Corporate Governance for Waqf: A Preliminary Proposal," 355.

6 Siti Mashitoh Mahamood, "Enakmen Wakaf (Negeri Selangor) 2015 (Enakmen 15): Suatu Ulasan Menurut Perspektif Syariah Dan UndangUndang," Jurnul Kanun 29, no. 2 (2017): 177. 
Assembly Proceedings were referred to identify the reasoning behind the promulgation of the 2015 Waqf Enactment. Information on Waqf development projects in Selangor were obtained from interviews conducted with officers from Perbadanan Wakaf Selangor. Secondary data from the websites and annual reports and bulletins of Majlis Agama Islam Selangor and Perbadanan Wakaf Selangor were also analysed to determine the activities and achievements of the Waqf administration in Selangor.

The discussion will be concluded with an analysis on whether the 2015 Waqf Enactment is sufficiently comprehensive or whether a transformative approach is needed to better suit the current needs of Waqf in Selangor.

\section{LEGAL HISTORY OF WAQF IN SELANGOR}

Mohammad Tahir Sabit had divided the Malaysian law on Waqf into 2 categories; the old and the new. He categorizes the old Waqf laws as laws passed prior to the 1980s and the new laws as Waqf laws which had been passed from the 1980s onwards beginning with the KaedahKaedah Wakaf (Johor) in 1983. ${ }^{7}$

\section{Pre-Independence Era}

The spread of Islam in South East Asia has been recorded as early as the 7th Century and is believed to be due to the preaching and propagation by Arab traders from the Middle East. ${ }^{8}$ Waqf was also

\footnotetext{
${ }^{7}$ Mohammad Tahir Sabit, "A Proposal for a New Comprehensive Waqf Law in Malaysia," in Waqf Laws and Management, ed. Syed Khalid Rashid, (Gombak: IIUM Press, 2017), 132.

8 Hisham Yaacob, "Waqf History and Legislation in Malaysia: A Contemporary Perspective," Journal of Islamic and Human Advanced Research (JIHAR), 3, no. 6 (2013): 395. In the paper Salehuddin Md. Dahlan, Zulkifli Yunos, and Nor Asiah Mohamad, "The Earliest Waqfs in Malaysia," it was recorded that Islam may have even been introduced in the Malay archipelago since the $7^{\text {th }}$ Century through the establishment of a Muslim Arab village in west coast Sumatera.
} 
amongst the principles which had been introduced with the advent of Islam and was integrated into the local fabric of life as Islam became a major religion in the region. It has also been influenced by the mindset and practices of the locals. For example, Waqf in other regions have historically been used for family Waqf, maintenance of educational institutions, aid for the poor, orphans and animals. In Malaysia, however, it has been noted that Waqf, even from the past, has mainly been created for religious purposes such as for the creation of mosques, suraus and burial sites. ${ }^{9}$ As these Waqfs were mostly administered and managed by the Penghulu or Imams, the number of recorded historical Waqf transactions from this period cannot be conclusively ascertained as there was no systematic method documentation before the period of colonization. Even if there was, priority was not given to maintain its upkeep. It was only upon the colonization by the British that a more systematic method of documentation and system of registration was introduced. ${ }^{10}$

Nuarrual Hilal states that during this period, there were no records of specific laws applicable to Waqf or its administration in any Malay States in Peninsular Malaysia and Borneo. ${ }^{11}$ However, he notes that there were general applications of Islamic principles based on Islamic legal codes. He therefore presumes that since Islamic law was the inherent law at that time, the applicable principles to matters and disputes pertaining to Waqf would have been Islamic principles. $\mathrm{He}$ further asserts that since Waqf had mainly been administered by the

\footnotetext{
${ }^{9}$ Sharifah Zubaidah Syed Abdul Kader, "The Legal Position of Waqf Lands in Malaysia," in Waqf Laws and Management, ed. Syed Khalid Rashid, (Kuala Lumpur, Malaysia: IIUM Press, 2017), 85.

10 Siti Mashitoh Mahamood, Waqf in Malaysia: Legal and Administrative Perspective (Kuala Lumpur, Malaysia: University of Malaya Press, 2012), 28. ${ }^{11}$ Nuarrual Hilal Md Dahlan and Abdul Rani Kamarudin, "Wakaf in Malaysia: Its Legal Evolution and Development," Shariah Law Reports Articles 1 (2006): 2 .
} 
Qadhis, Imams and Mosque Committees, Islamic legal texts ${ }^{12}$ would have been referred to had there been any disputes involving Waqf $^{13}$

\section{During British Colonization}

Different from the period of colonization by the Portuguese and the Dutch, the British had heavily influenced the practice of Waqf in Malaysia, Selangor included. They had periodically set aside principles derived from Islamic legal texts and customary practices and had replaced them with English Laws and legal principles through the Charters of Justice. The effect of colonization has also been said to have usurped Waqf lands from the Muslim societies and had disrupted its management. ${ }^{14}$

Waqf however, at that time was not a concept alien to the British. Having much experience with Waqf in India, the British had also participated in Waqf through the creation of awqaf irsad, both in the Straits Settlements and in the Federated Malay States. The British Resident in Selangor at that time had also approved and granted funds to maintain and establish mosques in the state. ${ }^{15}$ Although the British had greatly interfered with the administration of Waqf in certain states such as Penang and Johor, Abdul Fattah in his thesis mentioned that the British in Selangor at this time had no interest in administering Waqf. ${ }^{16}$

The British introduced the Torrens System of land titles registration which in effect had allowed for a more systematic manner in recording land holdings. Through the Torrens system, a cadastral survey was

\footnotetext{
${ }^{12}$ Among the Islamic legal texts which has been referred to are; Fath al Qarib (Melaccan Empire), the Mejelle (Johor), Bughyat al Mustarshidin and Mu'in al-Hukkam (Kelantan). Nuarrual Hilal Md Dahlan and Abdul Rani Kamarudin, "Wakaf in Malaysia: Its Legal Evolution and Development," 3. ${ }^{13}$ Ibid, 2.

${ }^{14}$ Murat Cizakca, A History of Philanthropic Foundations: The Islamic World from the 7th Century to the Present (Boğaziçi University Press, 2002),117.

15 Siti Mashitoh Mahamood, Waqf in Malaysia: Legal and Administrative Perspective, 34.

${ }^{16}$ Abdul Fatah bin Haji Khalid, "Islamic Law and Land in the State of Selangor, Malaysia: Problems of Administration and Islamisation" (PhD diss., University of Edinburgh, 1988), 247.
} 
conducted which properly recorded the measurement and other details relating to land ownership. Although the status of Waqf lands were not recorded on the register at that time, implementation of the Torrens system facilitated the identification of lands that were later to be identified as Waqf lands. Selangor adopted the Torrens System in 1882 through the General Land Regulations 1882. ${ }^{17}$

\section{Post- Independence}

Before independence, the British had centralized the management of Waqf in Selangor. Powers to manage Waqf were granted to the Majlis Agama Islam Selangor ('MAIS') as the State Religious Council (SIRC) through the Laws for Administration of the Religion of Islam 1952. ${ }^{18}$ This position continued even after independence.

Provisions on Waqf contained in the above enactment however were not comprehensive. Among the provisions were on the appointment of the SIRC as the sole trustee of all types of Waqf and any kind of charitable trust made according to Islamic law. However, the provisions did not outline the duties, responsibilities and scope of power of the SIRCs as trustees, and the interpretation of Waqf was also not thoroughly covered. This had inadvertently cast doubts on the scope and limits of Waqf.

The Laws for the Administration of the Religion of Islam 1952 however was repealed ${ }^{19}$ and was replaced by the Administration of Islamic Law Enactment 1989. ${ }^{20}$ It was only in 1999 that the Selangor

17 Richard $\mathrm{Wu}$, "Implementation of Land Title Registration System in Malaysia: Lessons for Hong Kong," Malayan Law Journal Articles 1 (2011): 68.

${ }^{18}$ Section 95 to 100 and Section 103 of the Laws for Administration of the Religion of Islam 1952 governed matters relating to Waqf.

${ }^{19}$ Section 87 of the Administration of Islamic Law Enactment 1989 states that Part I, II,III,V,VI,VII,VIII,IX of the Laws of the Religion of Islam 1952 has been repealed.

${ }^{20}$ The Administration of Islamic Law Enactment 1989 has since been repealed and replaced with the Administration of Law Enactment (State of Selangor) 2003 through Section 123 of Enactment 2003. 
Waqf Enactment 1999 was promulgated specifically for the administration and management of Waqf in Selangor.

\section{Waqf Enactment (State of Selangor) 1999}

The 1999 Waqf Enactment, although introduced in 1999, was only enforced on $1^{\text {st }}$ July 2004 . Repealing the provisions relating to Waqf in the Laws for the Administration of the Religion of Islam 1952, the 1999 Waqf Enactment contained both substantive and administrative clauses on Waqf. ${ }^{21}$

Among the main features of the 1999 Waqf Enactment were:

i. Conditions for the creation of Waqf and restrictions on its creation; ${ }^{22}$

ii. The power and responsibility of MAIS as the sole trustee of Waqf in Selangor; ${ }^{23}$

iii. Conditions for istibdal; ${ }^{24}$

iv. Handling of mawquf and its proceeds; ${ }^{25}$

v. The appointment, power and responsibility of the Waqf Management Committee in managing Waqf in Selangor. ${ }^{26}$

It can be seen from the above that the provisions in the 1999 Enactment were much more comprehensive than the piecemeal provisions on Waqf in the Administration of the Religion of Islam Enactment 1952.

${ }^{21}$ Siti Mashitoh Mahamood, Waqf in Malaysia: Legal and Administrative Perspective, 58.

${ }^{22}$ Part II of the Waqf Enactment 1999.

${ }^{23}$ Part VIII of the Waqf Enactment 1999.

${ }^{24}$ Part VI of the Waqf Enactment 1999.

${ }^{25}$ Part V of the Waqf Enactment 1999.

${ }^{26}$ Part VII of the Waqf Enactment 1999. 


\section{EVOLUTION OF WAQF LAWS AND PRACTICES IN SELANGOR}

A call for a more comprehensive Waqf legislation was made by scholars to further accommodate the growing needs for effective Waqf management and to resolve issues which have been identified in the management of Waqf in the state. ${ }^{27}$

In a bid towards increasing the number of productive Waqf properties in Malaysia through the $9^{\text {th }}$ Malaysia Plan, it is observed that Cash Waqf and Waqf Shares have become a well-accepted means to raise money to fund Waqf properties investment by the SIRCs. ${ }^{28}$ With this shift from endowing real properties to cash, shares, stocks, bonds and services as Waqf, legislation is needed to better recognize their validity and to regulate its handling by the managers of Waqf. Although the 1999 Waqf Enactment contain provisions on share Waqf, new provisions are also needed in the Enactment to regulate other types of mawquf.

\section{Shift in Waqf Management}

As mentioned above, by virtue of Section 21 of 1999 Waqf Enactment, the management of Waqf in Selangor rests on the Waqf Management Committee. The Committee would develop policies which in turn would be executed by the Wakaf Unit under MAIS. The Wakaf Unit consisted of the Registrar of Waqf, the Assistant Registrar and three

${ }^{27}$ Tunku Alina Alias and Murat Cizakca, "Should Malaysian States Have A Fresh Approach to Waqfs? A Proposal for A Model Waqf Enactment," ISRA International Journal of Islamic Finance 6, no. 2 (2014): 133-40; Hisham Yaacob, "Waqf History and Legislation in Malaysia: A Contemporary Perspective"; Rohayu Abdul Majid and Rosli Said, "Permasalahan Pengurusan Hartanah Wakaf Di Malaysia," International Surveying Research Journal 4, no. 1; Mohammad Tahir Sabit, "A Proposal for a New Comprehensive Waqf Law in Malaysia."

${ }^{28}$ Mustafa Omar Mohammed and Norhaliza Mohd Nor, "Categorization of Waqf Lands and Their Management: The Case of the State of Selangor," in Waqf Laws and Management, ed. Syed Khalid Rashid, (Selangor: IIUM Press, 2017), 230. 
staffs. ${ }^{29}$ This unit however is insufficient in catering to the growing needs of Waqf in the state. Limited human resources, heavy workload and incomplete Waqf data was cited as the problems which had affected Waqf management at that time. ${ }^{30}$

Singapore on the other hand, having realized the great potential which Waqf carries as a tool of poverty alleviation, has formed a separate company which specializes in managing its Waqf properties. By contracting a specialized company to manage Waqf assets, Waqf in Singapore is seen to be handled more efficiently and effectively.

To further develop and optimize the Waqf properties in Selangor, the above practice was emulated in Selangor through the incorporation of Perbadanan Wakaf Selangor (PWS) through the Wakaf Corporation of Selangor Order 2011. As the Wakaf Corporation of Selangor Order 2011 is to be read together with the 1999 Enactment $^{31}$, it was identified however that certain jurisdictional conflicts arose between the Waqf Management Committee and PWS in terms of powers to manage Waqf. As the Waqf Management Committee was recognized as the Waqf managers in the 1999 Enactment, there was an overlapping responsibility between the Committee and PWS in managing Waqf in the state. ${ }^{32}$ A new Waqf Enactment is therefore needed to recognize the duties and responsibilities of PWS as the new Waqf managers in the state to replac the Waqf Management Committee.

As a subsidiary to MAIS, among the responsibilities of PWS is to promote, stimulate, facilitate, undertake and develop properties and products of Waqf owned by MAIS. To undertake this responsibility, PWS is comprised of five (5) departments, as illustrated in Figure 2 below, consisting of officers from different fields and backgrounds

29 Sharifah Zubaidah Syed Abdul Kader, "Kerangka Undang-Undang Pengurusan Wakaf Di Malaysia: Ke Arah Keseragaman Undang-Undang: Legal Framework for Waqf Management in Malaysia: Towards Uniformity of Laws," Kanun- Jurnal Undang-Undang Malaysia, (2016): 111.

${ }^{30}$ Nurul Azma Abu Bakar, Muhammad Nasri Md. Hussain, and Abu Bakar Hamed, "Scrutinizing the Effects of Restructuring in Perbadanan Wakaf Selangor," International Journal of Accounting, (2017): 17.

${ }^{31}$ Order 2 of the Establishment of Wakaf Corporation of Selangor Order 2011.

32 Discussed further under heading "Power and Responsibility of PWS and Majlis Agama Islam Selangor". 
such as Islamic studies, finance, urban planning and development, and engineering.

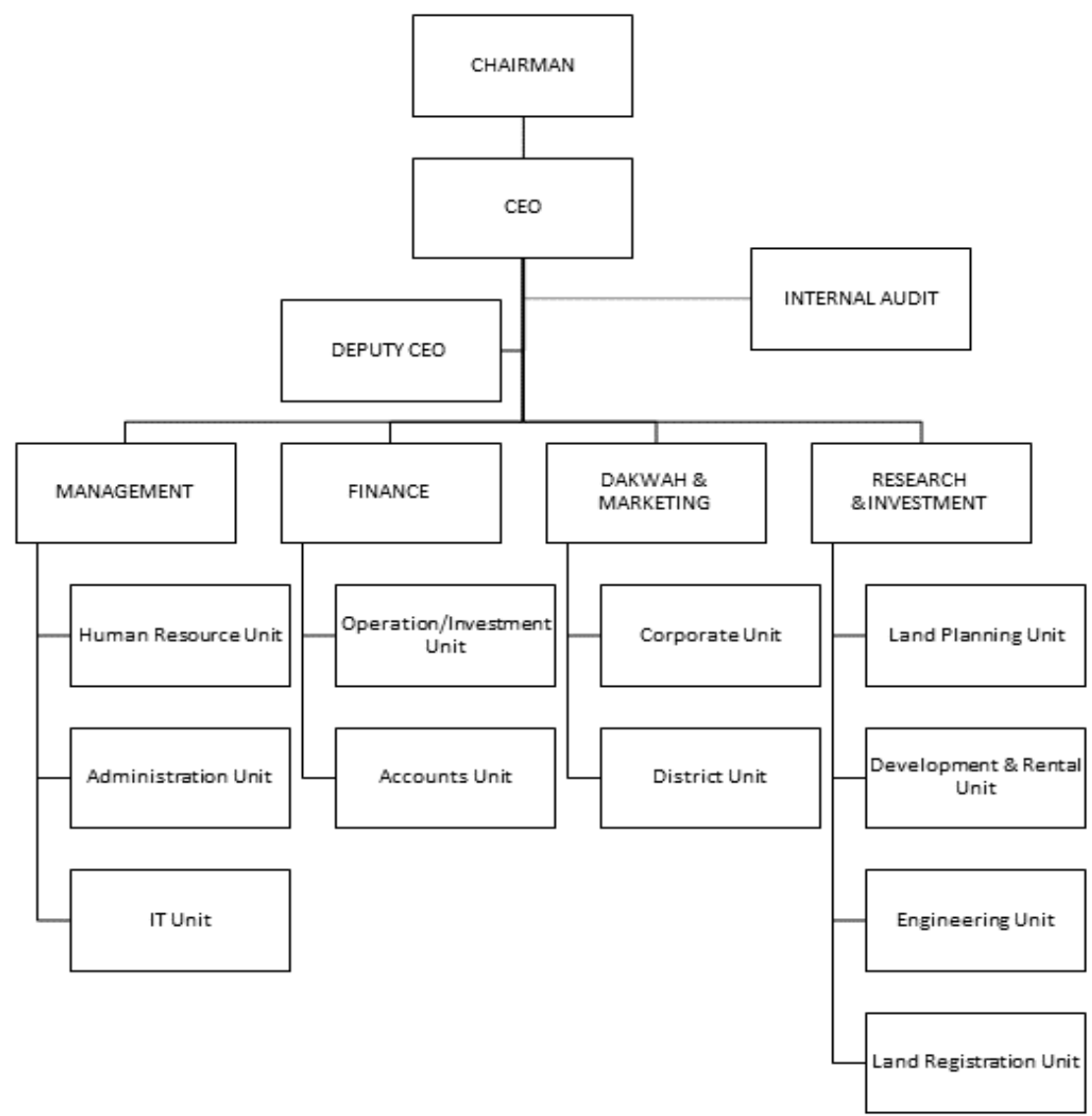

Figure 2: Organizational Chart of $\mathrm{PWS}^{33}$

33 Derived from information obtained from Perbadanan Wakaf Selangor, Majlis Agama Islam Selangor, accessed September 10, 2019, http://www.wakafselangor.gov.my/. 
Through the incorporation of PWS, it can be seen that the development of the Waqf institution in Selangor is heading towards a positive direction. Since its incorporation, PWS has introduced various Waqf schemes such as Wakaf Emas, ${ }^{34}$ Wakaf Seni, ${ }^{35}$ and Wakaf Wasiat $^{36}$.Through PWS's promotional activities, the Selangor Share Waqf scheme contributions has also experienced significant increase. ${ }^{37}$ As seen in Table 1 below, the contributions through the Share Waqf Scheme in both Waqf Am and Waqf Khas in the state of Selangor have steadily increased from the year 2012 to 2016.

\footnotetext{
${ }^{34}$ Through a research conducted by PWS, it was found that $80 \%$ of Wakaf contributors in Selangor are female. Taking this into consideration, PWS has introduced the Wakaf Emas scheme which allows women to contribute their gold as Waqf in Selangor. Further information on this scheme is available at Perbadanan Wakaf Selangor, "Pembangunan Hartanah Wakaf," Buletin Perbadanan Wakaf Selangor MAIS, vol. 1, September 29, 2013, http://www.wakafselangor.gov.my/images/PWS/buletin/Buletin_PWS_Bil.1 2013.pdf.

35 The Wakaf Seni scheme was introduced by PWS in efforts to establish relationships with artists and members of the creative art industry who are interested in contributing to Waqf through promotions in the form of arts. Further information on this scheme is available at Selangor.

${ }^{36}$ Wakaf Wasiat is a scheme introduced by PWS and MAIS which allows the public to contribute to Waqf after their demise. Further information on this scheme is available at Perbadanan Wakaf Selangor, "Usahasama Projek Komersil Hartanah Wakaf Selangor," Buletin Perbadanan Wakaf Selangor MAIS, vol. $\quad 1, \quad$ September 29, 2014, http://www.wakafselangor.gov.my/images/PWS/buletin/Buletin_PWS_Bil.1 2014.pdf.

${ }^{37}$ The share Waqf scheme was introduced by MAIS in Selangor since 2005. From the period of 2005 to 2011, it was recorded that the total Waqf share contribution stood at RM 7,216,206.00. See Perbadanan Wakaf Selangor, Buletin Perbadanan Wakaf Selangor MAIS, vol. 1, 2012, 10.
} 
Table 1 : Total Contribution Through Selangor Share Waqf Scheme from $2012-2016^{38}$

\begin{tabular}{|c|c|c|}
\hline Year & Waqf Am & Waqf Khas \\
\hline 2012 & RM 4,004,452.00 & RM 7,648,764.00 \\
\hline 2013 & RM 6,251,011.00 & RM 11,815,482.00 \\
\hline 2014 & RM 8,030,089.00 & RM 18,350,268.00 \\
\hline 2015 & RM 7,061,854.00 & RM 25,325,048.00 \\
\hline 2016 & RM 7,869,136.39 & RM 35,136,362.85 \\
\hline Total & RM 33,216,542.39 & RM 98,275,924.85 \\
\hline
\end{tabular}

Apart from Waqf fund projects, PWS has also ventured into a Waqf estate development project through a Joint-Venture Agreement with Nada Sepakat Corporation (M) Sdn. Bhd. to develop two adjacent parcels of Waqf land measuring 2.3ha in Shah Alam. The commercial housing project is expected to significantly increase the investment of the Waqf property and is projected to have a gross development value of RM40 million. ${ }^{39}$

Another ongoing PWS land development project involves a commercial housing project with Urus Maju Ehsan (M) Sdn. Bhd. called UME- Orked in Kampung Lombong, Shah Alam. Apart from commercial housing projects, PWS and Urus Maju Ehsan (M) Sdn. Bhd. are also embarking into other projects such as maintenance work for existing Waqf assets in Bukit Jelutong and Kolej Sultan Alam Shah in Klang. ${ }^{40}$

\footnotetext{
38“Terimaan Sumbangan SWS," Perbadanan Wakaf Selangor, Majlis Agama Islam Selangor, accessed September 17, 2018, http://www.wakafselangor.gov.my/index.php?option=com_content\&view=ar ticle\&id=215\&Itemid=591\&lang=en.

${ }^{39}$ Perbadanan Wakaf Selangor, "Usahasama Projek Komersil Hartanah Wakaf Selangor."

${ }^{40}$ Mohd Azli Bin Md Yusof, "Development of Waqf Land: Challenges and Opportunities from a Developer's Perspective," (paper presented at 7th National Seminar on Best Practices in Construction Industry 2017).
} 
However, even with the increase in participation from the public through various Waqf schemes in Selangor and various development projects, there were still several issues which were seen to have limited the potential of Waqf in Selangor. Among the issues which have been identified are as follows:

\section{i. $\quad$ Lack of Waqf Managers due to MAIS being the sole trustee of Waqf}

A major disadvantage of having a single body holding sole trusteeship and management of a Waqf property is that in cases of mismanagement or oversight, no other body or individuals could take over the management of the Waqf property. An example was brought to light by Dr. Yaakob Bin Sapari, Selangor State Assemblyman of Kota Anggerik, Selangor during the $13^{\text {th }}$ Selangor State Assembly, of a case where an orphanage was endowed as Waqf. He has been recorded to have said that due to alleged mismanagement on the part of the Waqf managers, the orphanage was left in a dilapidated state. As Waqf is irrevocable and the SIRCs are the sole trustees and managers of the Waqf in the state, the waqif was unable to reclaim the property. ${ }^{41}$ Although this allegation has not been proven, such possibility is a concern.

Cizakca warns against the excessive degree of centralisation of Waqf management in Malaysia. ${ }^{42}$ It is opined that with the appointment of other parties as Waqf managers and with the added support of the SIRCs, the welfare of the property will be better protected. Such support could be in the form of providing periodic training ${ }^{43}$ to the managers and providing free legal advice and representation in events of legal dispute.

41 "Mesyuarat Kedua Penggal Ketiga Dewan Negeri Selangor Darul Ehsan Ketiga Belas Tahun 2015, 17-20 Ogos" (Shah Alam: Dewan Negeri Selangor Darul Ehsan, 2015), http://dewan.selangor.gov.my/hansard1502.

${ }^{42}$ Cizakca, A History of Philanthropic Foundations: The Islamic World from the 7th Century to the Present, 123.

${ }^{43}$ Curriculums could include training in the area of property management and development, on the applicable land and Waqf laws and on the Fiqh of Waqf itself. 


\section{ii. Registration of Waqf Properties}

Registration of Waqf properties has been attributed as one of the main issues beleaguering the development of Waqf in Malaysia. ${ }^{44}$ This issue is no different in Selangor.

One of the problems which has been highlighted is concerning land that had been endowed through Waqf to mosques or suraus. It was pointed out that some of the administrators of mosques had failed to declare the land as Waqf which therefore lead to confusion on its status. ${ }^{45}$ Therefore, it was proposed that MAIS should make it compulsory for every mosque to declare and ensure that every land which had been made as Waqf for its benefit be registered as Waqf. This is to ensure that the benefits derived from the Waqf property is accounted for and is managed effectively. ${ }^{46}$

The 2015 Waqf Enactment therefore was promulgated to remedy the abovementioned issues.

\section{Waqf Enactment (State of Selangor) 2015}

The 2015 Waqf Enactment came into effect on $19^{\text {th }}$ October $2015 .{ }^{47}$ It comprises of 49 sections which are divided into 10 parts and it aims to address loopholes in the 1999 Waqf Enactment. Among the reasons for its promulgation, as discussed during the meeting of the Selangor State Assembly, was to improve the execution of Waqf. Reportedly, it was observed that a number of Waqf properties in Selangor are being left idle or that its usage has not been maximised to its fullest potential. ${ }^{48}$

Based on comparison between the two Waqf enactments, it is observed that the 2015 Waqf Enactments contains:

\footnotetext{
${ }^{44}$ This is extensively discussed in Sharifah Zubaidah Syed Abdul Kader and Nor Asiah Mohamad, "Legal Framework for Management of Waqf Land in Malaysia," Shariah Law Report Articles 4 (2014): xii.

45 "13th Selangor State Assembly, Third Term, Second Meeting," 64. ${ }^{46}$ Ibid, 63.

47 Siti Mashitoh Mahamood, "Enakmen Wakaf (Negeri Selangor) 2015 (Enakmen 15): Suatu Ulasan Menurut Perspektif Syariah Dan UndangUndang," 145.

48 "13th Selangor State Assembly, Third Term, Second Meeting," 63.
} 
i. Introduction of new provisions which regulate new Waqf management practices;

ii. Removal of certain provisions; and

iii. Paraphrasing of previous provisions contained in 1999 Waqf Enactment for purposes of clarity and greater understanding.

In general, the basic tenets of Waqf remain unchanged and is still maintained in the 2015 Waqf Enactment. New provisions on the management aspect of Waqf however has since been added. The features of the 2015 Enactment are further explained as follows:

\section{Expansion on Interpretation}

A notable change brought about by the 2015 Waqf Enactment is the expansion of the term 'Waqf'. Under the 1999 Waqf Enactment, Waqf was interpreted as dedication of "any property". Property was further interpreted as either movable or immovable property or interest therein.

Under the 2015 Waqf Enactment however, Waqf or Wakaf (as referred to in the enactment) is expanded to include properties, expertise and services. The interpretation of property has also been further widened to include;

i. ...intellectual property;

ii. Any benefit or interest in any movable property, immovable property or intellectual property;

iii. Any right, interest, title or otherwise in connection with movable property, immovable property or intellectual property; and

iv. Expertise and services having value in accordance with Hukum Syarak;

Scholars agree that this expansion is beneficial as the Islamic legal system recognises services and expertise as property. ${ }^{49}$ Siti Mashitoh

49 Siti Mashitoh Mahamood, "Enakmen Wakaf (Negeri Selangor) 2015 (Enakmen 15): Suatu Ulasan Menurut Perspektif Syariah Dan UndangUndang," 147; Mohd Daud Bakar, "Waqf: Financial Instrument Vis-a Viz Religious Instrument," (paper presented at Muktamar Waqf Iqlimi IV 2017). 
gave an example as to how this could be utilized in Waqf universities where the lecturers could be examiners for masters and $\mathrm{PhD}$ students for free (and regard it as their Waqf). She further mentions that this recognition in the Waqf enactment is important to validate this practice and is in line with the awareness on Waqf which is expanding in time. ${ }^{50}$

The 1999 Waqf Enactment interpreted Waqf to only include properties, and this could be due to a fiqh opinion that Waqf should be perpetual and indefeasible. ${ }^{51}$ If services and expertise were to be included in the interpretation of Waqf, it would raise questions relating to the perpetuity of the mawquf. Standards, formulated by MAIS, which are in line with the requirements of Waqf, would have to be placed to identify whether a service could be appropriately considered as Waqf.

However, it would be of great benefit if services were identified as an appropriate mawquf for Waqf, as many forms of dissemination of knowledge and help could be offered for free. With the expansion on the interpretation of 'property' to also include intellectual property, experts can also contribute in offering books or educational videos free of charge. Furthermore, this would invite more people to offer their time and expertise in developing Waqf properties.

Another term which was present in the 1999 Enactment but has been further explained and expanded in the 2015 Waqf Enactment is on the concept of Marad Al-Maut and the practice of making Waqf through wills. The change in requirement on what constituted Marad Al-Maut was noted by Siti Mashitoh due to the decision in the case of Mahdi bin

50 Siti Mashitoh Mahamood, "Enakmen Wakaf (Negeri Selangor) 2015 (Enakmen 15): Suatu Ulasan Menurut Perspektif Syariah Dan UndangUndang," 147.

${ }^{51}$ Majority of Hanafi scholars believe that the subject matter of Waqf should exist in perpetuity. See Mohd Tahir Sabit, "The Concept and Objective of Waqf," Shariah Law Report Articles 1 (2004): x; Shirbaini, Al Imam Shams Al Muhammad Ibn Al Khatib. The Book of Endowment (Kitab Al-Waqf) from Mughni Al-Muhtaj Ila Ma'rifat Ma'ani Alfaz Al-Minhaj. Translated with an Introduction, Appendices and Notes by Nicholas Mahdi Lock. Kuala Lumpur, Malaysia: IBFIM, 2015, 10. 
Ab. Hamid v. Mohamad Iqwan bin Yahaya. ${ }^{52}$ The concept of Marad alMaut was further expanded in the 2015 Waqf Enactment as it can also be related to the practice of making Waqf through wills. Siti Mashitoh opines that the 1999 Enactment is inadequate and does not properly address the concept of al-Waqf bi-al Wasiyyah. ${ }^{53}$ Therefore, through Part VII of the 2015 Waqf Enactment, the practice of making Waqf through wills is further addressed.

\section{Power and Responsibility of PWS and Majlis Agama Islam Selangor}

Certain jurisdictional conflicts have arisen between the Waqf Management Committee and PWS in terms of power to manage Waqf. It was further mentioned that the 1999 Waqf Enactment was insufficient in recognizing the duties and responsibilities of PWS. It was therefore the task of the 2015 Waqf Enactment to remedy this conflict and properly recognize PWS as the managers of Waqf in Selangor.

\section{i. Recognition of PWS as Waqf Managers}

To formally recognize PWS as Waqf managers in Selangor, the 2015 Waqf Enactment has accorded power to MAIS to appoint third parties to manage Waqf on its behalf. This position, prior to 2015, has not been undertaken by any other states in Malaysia since the promulgation of the Islamic administrative laws of the states. Since 2015, states such as Perak and Terengganu have also accorded the same power to their respective SIRCs through their Waqf Enactments. ${ }^{54}$

This delegation of power is seen as a solution in lightening the burden carried by MAIS in managing Waqf and handing over the task to individuals who are more skilfully equipped in property

\footnotetext{
52 Siti Mashitoh Mahamood, "Enakmen Wakaf (Negeri Selangor) 2015 (Enakmen 15): Suatu Ulasan Menurut Perspektif Syariah Dan UndangUndang," 148.

${ }^{53}$ Mahamood, 148.

${ }^{54}$ Section 27 of Wakaf (Perak) Enactment 2015 and Section 4 of the Wakaf (Terengganu) Enactment 2016.
} 
development. Although PWS was established as the Waqf manager for Selangor, the 2015 Waqf Enactment reiterates the position of MAIS as the sole Waqf trustee in Selangor. ${ }^{55}$ This reiteration is important as it solidifies the position of MAIS as the highest body for administering Waqf in Selangor. As MAIS also holds the power to formulate Waqf related policies which binds the Waqf managers such as PWS, it is therefore appropriate that authority to administer Waqf should preside in them. The full powers and responsibility of MAIS in administering Waqf is listed down under Part II of the 2015 Waqf Enactment.

\section{ii. Powers and Responsibility of PWS}

Under Section 2 of the 2015 Waqf Enactment, PWS is defined as the Wakaf Corporation of Selangor which was established by the Establishment of Wakaf Corporation of Selangor Order 2011. Reading together the above Order and the 2015 Waqf Enactment, among PWS's responsibilities are; to execute, facilitate, undertake and develop properties and products of Waqf owned by MAIS. They are also tasked with registration and maintenance of information on Waqf properties in the state. Apart from the powers which had been bestowed under the Order, by virtue of the 2015 Waqf Enactment, PWS now holds the power to issue Waqf shares, accept shares, bonds, sukuk or other instruments for valuable guarantee.

However, the powers of PWS is not absolute. Under Section 8 of the 2015 Waqf Enactment, in executing its duties and powers, PWS is still subject to the control and direction of MAIS. Furthermore, PWS has the duty to report to MAIS on its activities and performance. This arrangement retains MAIS as sole trustee but allows it to delegate the management overhead which would otherwise consume its manpower resources.

As shown in Figure 2 above, PWS as a corporation comprises of individuals from different backgrounds and expertise relevant to property development. This range of expertise from the private sector allows MAIS to utilize professionals that may not exist in their current staff and increases the effectivity and efficiency of the decision-making process. A degree of supervision however is still needed from MAIS to

${ }^{55}$ Section 4 (c) and Section 8 of the Waqf Enactment 2015. 
ensure that everything done by PWS is according to the Shariah and in the spirit of Waqf.

There is however a concern by the authors as to whether such degree of control by MAIS is needed as this adds layers of bureaucracy and thus reduces management efficacy in the institution of Waqf in the state. Among the disadvantages which this arrangement could possibly pose are:

\section{- Slow decision making}

A considerable amount of time would be needed to obtain a decision from MAIS on whether a particular project or istibdal can take place. This will impede the development of Waqf properties in Selangor, especially with the large number of Waqf lands in the state.

\section{- Communication problems}

Layers of bureaucracy may lead to loss of information. In other words, the decisions made by the upper levels (MAIS) may be lost in translation when conveyed to the executives in PWS and then further conveyed to the officers in PWS who will be executing the directions. Directions passed through written communications or short orders may also be misunderstood where certain nuances that were internally discussed in MAIS may not be passed along.

\section{- Inflexible and rigid}

An organization with many layers of bureaucracy is deemed to be inflexible in the execution of duties by the officers. It is a standard concept in management theory where a flat organization with less layers allows it to be more flexible and responsive to changing circumstances.

A balance has to be struck which will allow PWS to manage the Waqf properties with flexibility and freedom without giving away the status of MAIS as the sole trustee and the highest authority over Waqf in Selangor. Although the Establishment of Wakaf Corporation of Selangor Order 2011 has outlined the rights and powers of PWS, it is felt that another rule or by-law could be drafted, by virtue of Section 43 of the 2015 Waqf Enactment, to further regulate the relationship between PWS and MAIS and one that would reflect the changes in position which has been made in the 2015 Waqf Enactment. 


\section{Recognition of third parties as Waqf Managers}

Among the problems faced in the maintenance of Waqf properties in Selangor is the possibility of inefficiency by the Waqf managers in handling Waqf properties. As of December 2016, there are 908 Waqf properties registered under MAIS. ${ }^{56}$ It is therefore expected that there should be increase in Waqf Managers to manage these properties.

As noted by scholars, ${ }^{57}$ one of the issues which has impeded the development of Waqf in Malaysia is the lack of resources on the part of the SIRCs (either in the form of manpower, expertise or financial resources). The number of properties is much larger than the number of staff available to the SIRC and the number of properties is still growing as time goes on. Therefore, by allowing MAIS and PWS to appoint other entities as third parties to manage Waqf properties, it would lessen their burden in overseeing every single Waqf property and this in turn will reduce the number of idle Waqf lands in the state.

By allowing third parties to manage and maintain the Waqf property, it would hopefully attract others to endow their land as Waqf without the need to relinquish total control over the land. The Waqif can recommend for the appointment of his representative (or even himself) to manage the property and can oversee any development project planned on the land. This delegation of power however is still subject to the authority of and conditions laid down by PWS and MAIS. $^{58}$

56 "Statistik Hartanah Wakaf." Accessed December 7, 2019. http://www.wakafselangor.gov.my/index.php?option=com_content\&view=ar ticle\&id $=213 \&$ Itemid $=583 \&$ lang $=$ en.

${ }^{57}$ See Noor Aimi Bt Mohd Puad, Nurauliani Bt Jamlus Rafdi, and Wan Shahdila Shah Bt Shahar, "Issues and Challenges of Waqf Instrument: A Case Study in MAIS," (paper presented at Conference on Management and Muamalah, 2014); Siti Mashitoh Mahamood, Waqf in Malaysia: Legal and Administrative Perspective, 124 ,Sohaimi Mohd. Salleh and Syarqawi Muhammad, "Waqaf Development in Malaysia: Issues and Challenges," (paper presented at Dubai International Endownments' Investment, 2008).

${ }^{58}$ Section 4(2) and (3) of Waqf Enactment 2015. 


\section{Vesting of Waqf Properties}

The issue of Waqf registration has also been cited as one of the prominent challenges beleaguering the development of Waqf in Malaysia. This is related to other problems such as disputes on the status of the Waqf by the Waqif's descendants, trespass and illegal occupation. To remedy this problem, legislators in the 2015 Waqf Enactment had included several provisions with regards to the vesting of Waqf properties and the registration process by PWS.

In the 1999 Waqf Enactment, section 13(e) invalidates any Waqf if it is inconsistent with any written law. Therefore, if any Waqf is not registered/vested as per required under the National Land Code 1965, it may invalidate the Waqf. This position is not in line with the spirit of Waqf in Islam whereby if conditions of Waqf are met, the property is deemed as Waqf and therefore ownership no longer stands with the Waqif. This position was adopted by the Court of Appeal in the case of Majlis Agama Islam Selangor v Bong Boon Chuen \& Ors [2008] 6 MLJ 488.

To uphold the spirit and principles of Waqf, the 2015 Waqf Enactment no longer invalidates Waqf that is inconsistent with any written law. Section 13 of the 2015 Waqf Enactment states that a Waqf will take into effect once all the pillars and conditions for its creation has been fulfilled. Once it has taken into effect, it cannot be sold, be given as hibah or inherited by any person.

To further strengthen the registration procedure of Waqf in the state, the 2015 Waqf Enactment necessitates the creation and upkeep of a Waqf registry. ${ }^{59}$ The 2015 Waqf Enactment also requires the appointment of a Chief Registrar of Waqf and Registrars of Waqf whose responsibilities involve taking charge of all matters pertaining to registration of all mawquf. This includes; keeping and maintaining a Waqf registry for all mawquf, keeping and holding all instruments, document of titles relating to the mawquf, and reporting to MAIS on the status of the Waqf registry. MAIS will then in turn be responsible to publish the list of all properties, investments and assets in the State Gazette. ${ }^{60}$

${ }^{59}$ Section 15 of the Waqf Enactment 2015.

${ }^{60}$ Section 16 of the Waqf Enactment 2015. 
The above can be seen as an attempt by the legislators to increase transparency and efficiency by MAIS and PWS. It is suggested however, to further increase transparency and efficiency in land administration. This can be done via a provision to allow PWS or its delegates to conduct surveys on Waqf properties in their respective state. This is similar to the provision used in India. ${ }^{61}$ Although PWS conducts surveys to determine the position, size, value of a Waqf property for purposes of Waqf development projects and to determine rental rates, the confirmation of express powers is needed to ensure that PWS can proactively protect the interest of the Waqf property.

\section{Other forms of mawquf}

As time progresses, other than immoveable properties, other types of mawqufs have been accepted as a form of Waqf. This includes cash, shares, bonds, sukuk and other instruments for valuable guarantees. Cash however was not expressly mentioned in the 1999 Waqf Enactment as an acceptable form of Waqf. Due to exigencies, it is discovered that a specific mention of cash is needed in the legislation to facilitate Waqf schemes such as cash contributions, salary deductions and Waqf Gold schemes.

The shift in practice is reflected in the 2015 Waqf enactment whereby cash Waqf and Waqf of shares has been explicitly mentioned and acknowledged as a form of mawquf. Under the 2015 Waqf Enactment, cash Waqf is interpreted as cash contribution, gold value or those similar thereto from any person for purpose of Waqf. Further widening the spectrum of mawquf, the 2015 Waqf Enactment further allows for Waqf to be made in the form of shares, bonds, sukuk and other instruments for valuable guarantees. ${ }^{62}$ Waqf of share is to be distinguished from Waqf share $^{63}$, a mawqu $f$ which has been recognized under the 1999 Waqf Enactment.

\footnotetext{
${ }^{61}$ Section 4(1A) of India's Wakf Act 1995.

${ }^{62}$ Section 23 of the Waqf Enactment 2015.

63 The Waqf Enactment 1999 interprets Waqf share as creation of a Waqf through the issuance of shares which are subsequently endowed as a Waqf by the purchaser to the Majlis.
} 
Siti Mashitoh distinguishes between Waqf shares and Waqf of Shares and explains that the former involves the issuance of sale of shares which are divided into small units based on a specific value to any individuals, corporations or institutions. ${ }^{64}$ These shares are of properties which are purchased or to be purchased by MAIS for purpose of share offerings which are later to be made as Waqf to MAIS. The latter on the other hand are the Waqf of existing properties such as shares, bonds, sukuk or other instruments for valuable guarantee, including benefits accruing from the aforementioned shares with condition that the business and investment are in line with Hukum Shara'.

The recognition of the abovementioned mawquf is important in terms of improving transparency and efficiency in handling them by the managers of Waqf. These mawqufs will have to be listed and recorded in the Waqf registry and later gazetted.

\section{Offences relating to Waqf}

Recent trend has emerged whereby certain individuals or organizations have been organising Waqf related activities without approval from MAIS. Although some of the activities could have been conducted by the organizers in good faith and for the benefit of the society, one cannot dispute the possibility of certain individuals collecting funds or properties for their personal gains and not for Waqf. The public would then blame MAIS should it be discovered that the funds/properties they have contributed have not been used for purposes of Waqf. This would tarnish the reputation of MAIS as well as the reputation of Waqf and other Islamic charities and could possibly lead to a reluctance of the society to develop Waqf in the future.

A new provision under the 2015 Waqf Enactment therefore deems any activities relating to the administration and management of Waqf in the state of Selangor without approval from MAIS or PWS as an offence. ${ }^{65}$ Should the individual be convicted, he will be liable to a fine

${ }^{64}$ Siti Mashitoh Mahamood, "Enakmen Wakaf (Negeri Selangor) 2015 (Enakmen 15): Suatu Ulasan Menurut Perspektif Syariah Dan UndangUndang," 157.

${ }^{65}$ Section 45 of the Waqf Enactment 2015. 
not exceeding one thousand Ringgit or to imprisonment for a term not exceeding six months or both.

The above offence however seems to be referring to individuals who have managed Waqf without a written permission from MAIS and PWS and not to individuals who have obtained permission but however have committed misconducts while discharging their duties. Cases have been recorded in other countries whereby these appointed individuals have mishandled the funds and proceeds obtained from the Waqf. This kind of offence should also be noted by legislators as to highlight the importance of these Waqf managers in upholding the amanah bestowed on them.

Another offence which has been addressed in the Waqf Enactments is the offence of trespass and illegal occupation. There however seems to be a different approach as to how the offence is addressed in the 2015 Waqf Enactment. Under Section 45 of the 1999 Waqf Enactment, any act of trespass on Waqf land attracts a fine not exceeding five thousand ringgit and imprisonment not exceeding three years or both. A further continuing offender will be fined five hundred Ringgit for each day. The person will also need to demolish or clear the structures or obstructions erected on the Waqf property if so required by MAIS.

This stance is no longer followed in the 2015 Waqf Enactment. Under Section 44 of the new Enactment, MAIS or PWS is now given the power to take action against the trespasser under any written law. ${ }^{66}$ The prescribed punishment as previously laid down in the 1999 Waqf Enactment is no longer applicable. Siti Mashitoh opines that the prescribed punishment in the 1999 Waqf Enactment is insufficient and most of the time not proportionate to the damage which has been incurred on the property. ${ }^{67}$ Therefore, by granting flexibility on which law, is to be referred to and not adhering to a specific remedy which may not be favourable, it is hoped that the perpetrator would be appropriately punished according to the damages he had committed on the property.

One might however argue that by giving freedom to MAIS and PWS to take action under any written law, either civil or shariah, it

${ }^{66}$ Other written laws include civil action under Section $6 \& 7$ of the Specific Relief Act 1950 and Section 425 of the National Land Code 1965.

67 Siti Mashitoh Mahamood, Waqf in Malaysia: Legal and Administrative Perspective, 60. 
would belittle the role of the Shariah Courts while giving precedence to the civil courts. However, with the limited jurisdiction which the Shariah Courts have in imposing punishment, it would not be fair for the interest of the Waqf property to rely on the above prescribed punishment. Developers of Waqf lands have often had to deal with the problem of squatters and illegal tenants on Waqf lands and this has often times disrupted their projected development time frame and increase costs in Waqf development projects. An example was sighted in Ampang where the construction of a Surau on a Waqf land was disrupted due to the illegal occupation of a construction company which had used the land as a storage site for its construction materials. The problem persisted since 2014 and legal action was only initiated in 2017 to claim for vacant possession. ${ }^{68}$ Therefore, a provision which shows the seriousness of the offence is needed to ensure that these properties are protected and kept safe. However, it is suggested that a provision could be included in the Waqf Enactment which in the event of dispute, parties will be required to first attempt to solve the dispute amicably, either through formal or informal ADR processes, before referring the matter to Court. Through this, the number of cases brought to court and the corresponding litigation costs can be reduced.

\section{CONCLUSION}

Examination of the evolution of Waqf practices in Selangor above indicates that it is the right move for the legislators to replace the 1999 Waqf Enactment with the 2015 Waqf Enactment as it is better suited to the current practices of Waqf in the state. Several much-needed amendments have also been made to address problems which have occurred and have been experienced by MAIS in managing Waqf in the state. Being the only state in Malaysia which has repealed its previous Waqf Enactment for an improved version shows the state's continuing interest in improving the performance of its Waqf administration. It was the hope of the legislators that with an improved legal framework, the Waqf institution in the state would attract more parties in contributing

${ }^{68}$ Perbadanan Wakaf Selangor, Interview on December 27, 2017. 
to Waqf which in turn would benefit the surrounding Muslim community.

Through the analysis of the 2015 Waqf Enactments, it is found that the new enactment is indeed an improvement from the previous Waqf Enactment. It is found to be more comprehensive and has addressed several important issues, however several concerns have been put forward in this paper on its construction. It is understood that overpolicing could have a negative effect on the growth of the institution as it would lead to rigidity and little room for creativity. It is therefore not the intention of the writers to propose over regulation that would produce such rigidity. However, more could be done to ensure that the management of Waqf properties is conducted smoothly and with transparency while still allowing for flexibility to adapt to the various circumstances of each Waqf property.

Tunku Alina has promoted a Waqf model law which could be adopted by the states in Malaysia. ${ }^{69}$ In terms of improving the transparency of Waqf, she proposes among others, to give each Waqf a judicial personality and with it, transparency measures in terms of its accounts. By doing so and not consolidating every Waqf and its benefits and proceeds into a single Waqf fund, it will increase accountability on every single Waqf received by the SIRCs and ensure that the proceeds are not mishandled. This factor could perhaps be considered in the promulgation of future Waqf enactments in Malaysia. Other factors which could be considered are the revival of Family Waqf and perhaps the creation of a Waqf dispute resolution framework which would address future possible Waqf disputes.

Since the introduction of the 2015 Waqf Enactment, states such as Terengganu and Perak have also promulgated their own Waqf Enactments which could be seen as being just as comprehensive as the one in Selangor. Selangor has indeed been viewed as one of the states in Malaysia which has spearheaded the progress of Waqf through its Waqf legislation. Other states which have yet to enact their own Waqf Enactment or have yet to update their Waqf Enactment should consider following Selangor's footsteps in improving their own Waqf Enactments for more transparency and accountability. However, they

${ }^{69}$ Tunku Alina Alias and Murat Cizakca, "Should Malaysian States Have A Fresh Approach to Waqfs? A Proposal for A Model Waqf Enactment," ISRA International Journal of Islamic Finance 6, no. 2 (2014): 138. 
are free to promulgate provisions which are felt to be more suitable for the state. As an example, states might still have reservations in allowing third parties to manage its Waqf properties as it would lead to other problems such as mismanagement and misappropriation of Waqf funds. 